\title{
PENINGKATAN KEMANDIRIAN ANAK USIA 4 - 5 TAHUN \\ MELALUI METODE MENDONGENG DENGAN MEDIA BONEKA JARI DI TK PELANGI TENGGARONG SEBERANG TAHUN PELAJARAN 2016/2017
}

\author{
JUMANI \\ PG PAUD, FKIP, Universitas Widya Gama Mahakam Samarinda \\ ( umifadhiel10@gmail.com ) \\ Mahkamah Brantasari \\ PG PAUD, FKIP, Universitas Widya Gama Mahakam Samarinda \\ ( brantasari@gmail.com)
}

\begin{abstract}
This research aims to find out how to improve the independence of children aged 4-5 years through the method of storytelling with finger puppets in TK Pelangi Tenggarong Seberang in periode 2016/2017. This type of research using class action research methods (PTK) implemented in three cycles. The object of this research totalled 16. The data collection technique used was the observation that in the form of sheet of ebservations and documentation of the teacher and the student, while the results were analyzed using a quantitative descriptive method. The results of the analysis of the data indicates that an increase in cycle I became of $30.99 \%$ with. Cycle II increased to $58.86 \%$ with. Then in cycle III rose to $85.41 \%$ with appropriate expectations and growing category is growing very well. Conclusion on studies, that the application of the method of storytelling with finger puppets can increase self-sufficiency in children aged 4-5 years old in TK Pelangi about 77,60\%.
\end{abstract}

Keywords: self-sufficiency, methods of Storytelling, and Finger Puppets

\section{PENDAHULUAN}

Pendidikan anak usia dini adalah suatu upaya pembinaan yang ditujukan kepada anak sejak lahir sampai usia enam tahun yang dilakukan melalui pemberian rangsangan pendidikan untuk membantu pertumbuhan serta perkembangan jasmani dan rohani anak agar memiliki kesiapan dalam memasuki pendidikan lebih lanjut (Departemen Pendidikan Nasional, 2010: 3). Usia 4-6 tahun merupakan masa untuk meletakkan dasar pertama dalam mengembangkan kemampuan fisik, kognitif, bahasa, sosial emosional, konsep diri, disiplin, kemandirian, seni, moral, dan nilai-nilai agama. Oleh sebab itu, dibutuhkan kondisi dan stimulasi yang sesuai dengan kebutuhan anak agar pertumbuhan dan perkembangan anak tercapai secara optimal (Departemen Pendidikan Nasional, 2004: 1).

Menurut Yamin (2010: 4), masa usia dini adalah masa yang sangat menentukan bagi perkembangan dan pertumbuhan anak selanjutnya karena merupakan masa peka dan emas dalam kehidupan anak. Hal ini mengisyaratkan bahwa semua pihak perlu memahami akan pentingnya masa usia dini untuk 
optimalisasi pertumbuhan dan

atau acuan dalam melihat dan perkembangan. Sedangkan menurut mengevaluasi perkembangan dan Soefandi (2009: 7) usia dini atau disebut juga sebagai usia prasekolah adalah suatu masa ketika anak belum memasuki pendidikan formal. Oleh sebab itu, pada rentang usia dini adalah saat yang tepat untuk mengembangkan potensi dan kecerdasan anak. Pengembangan potensi anak secara terarah pada rentang usia tersebut akan berdampak pada kehidupannya di masa depan.

Pangastuti

(2014: mengungkapkan bahwa anak bersifat egosentris, memiliki rasa ingin tahu secara alamiah, merupakan makhluk sosial, unik, kaya degan fantasi, memiliki daya perhatian yang pendek, dan merupakan masa yang paling potensial untuk belajar. Namun, selain terfokus pada keunikan individu dalam mengoptimalkan perkembangan kecerdasan anak, guru dan orang tua harus memperhatikan beberapa hal. Halhal yang perlu diperhatikan menurut Azzet (2014: 30) meliputi : 1) Bukan orang dewasa, 2) Dunia bermain, 3) Berada pada fase berkembang, 4) Senang meniru, 5) Kreatif.

Yamin (2010: 102) mengatakan bahwa kemandirian anak usia dini dapat diukur dengan indikator-indikator yang telah dikemukakan para ahli, dimana indikator tersebut merupakan pedoman pertumbuhan anak. Indikator-indikator tersebut adalah Percaya diri, Bertanggung jawab, Disiplin dan Mengendalikan emosi.

Mengacu kepada Peraturan Menteri Pendidikan Nasional (Permendiknas) nomor 58 tahun 2009 tentang standar pendidikan anak usia dini, maka penilaian yang dilakukan guru terhadap peserta didik berdasarkan indikator kemandirian dan karakteristik sosial emosional anak usia 4-5 tahun dapat dikembangkan menjadi ; 1) Dapat berinteraksi dengan teman sebaya dan orang dewasa, 2) Dapat menjaga keamanan diri sendiri, 3) Menunjukkan rasa percaya diri, 4) Dapat menunjukkan kemandirian, 5) Mulai dapat menunjukkan emosi yang wajar, 6) Mulai menunjukkan sikap kedisiplinan, 7) Mulai dapat bertanggung jawab.

Fungsi bermain anak usia dini yaitu ; 1) Latihan pengambilan keputusan, 2) Memilih, 3) Mandiri, 4) Tuntas, 5) Kreativitas, 6) Percaya diri, 7) Pengembangan intelektual, 8) Pengembangan bahasa, 9) Bermain untuk pengembangan kecakapan sosial, 10) melakukan sebuah kesepakatan, 11) Bermain untuk pengembangan emosi, 12) Bermain untuk pengembangan fisik, 
13) Bermain untuk pengembangan kreativitas, 14) Bermain sebagai terapi.

Menurut Abdul (2014: 3), mendongeng adalah suatu kegiatan yang sangat mudah bisa dikatakan sebagai kegiatan yang sangat sederhana, mudah dan maknanya sangat lusa. Namun kenyataannya, tidak semua orang mampu melakukannya. Dalam pengertian yang sederhana, mendongeng adalah bertutur dengan intonasi yang jelas, menceritakan sesuatu hal yang berkesan, menarik, punya nilai-nilai khusus serta punya tujuan khusus.

Mendongeng bagi anak usia sini dalam mengajarkan kebenaran haruslah menarik, mengundang perhatian, dan tidak lepas dari konsep mendongeng. Beberapa teknik mendongeng yang dipergunakan oleh guru atau orang tua, yaitu: membaca langsung dari buku, menggunakan ilustrasi dari buku gambar, menggunakan papan flannel, menggunakan boneka, atau bermain peran dalam suatu cerita.

Menurut Zaman (2014: 6.14), boneka jari terbuat dari kain yang tidak mudah bertiras. Kain dibentuk sesuai dengan figur cerita. Satu narasi cerita dapat memerlukan hingga 10 boneka. Tujuan permainan boneka jari untuk mengembangkan bahasa peserta didik, meningkatkan keterampilan dan kreativtas peserta didik, mengajak peserta didik belajar bersosialisasi, dan bergotong royong di samping melatih keterampilan jari jemari tangan.

Madyawati (2016: mengungkapkan bahwa boneka jari (finger puppet) merupakan media permainan yang sangat cocok dimainkan orang tua dengan anak, mempermudah interaksi dan komunikasi serta melatih kreativitas. Sebuah dongeng yang disampaikan dengan cara yang menarik tentu akan lebih memikat anak-anak.

Menumbuhkan kemandirian anak memang sangat penting untuk dilakukan dengan kerjasama oleh seluruh pihak agar anak berkembang menjadi semakin baik sesuai dengan pertambahan usianya. Namun, menurut dokumentasi yang dilakukan oleh peneliti di TK Pelangi Tenggarong Seberang, saat pertama kali masuk sekolah peserta didik masih belum sepenuhnya dapat mengurus dirinya sendiri. Hal tersebut diketahui saat beberapa peserta didik masuk sekolah masih meminta untuk ditemani oleh orang tuanya. Jika keinginannya tidak dipenuhi maka peserta didik tersebut akan menangis dan tidak mau masuk ke kelas. Hal ini menunjukkan bahwa kemandirian peserta didik masih sangat perlu untuk ditingkatkan dalam bimbingan yang intensif, sebagaimana diketahui kemandirian peserta didik tidak terlepas 
dari pengaruh orang tua dan seluruh pihak di sekolah. Hal ini ditunjukkan melalui pengamatan awal yakni dari 16 anak di kelas, hanya 5 anak $(31,25 \%)$ dan yang mengikuti kegiatan belajar mengajar tanpa ditemani oleh orang tua. Sehingga, berdasarkan hasil dokumentasi tersebut, peneliti menyimpulkan bahwa diperlukan suatu metode yang efektif untuk mengembangkan kemandirian pada anak, namun tetap tidak terlepas dari suasana menyenangkan di kelas untuk anak-anak. Bekerjasama dengan pihak sekolah, peneliti mencoba untuk mengembangkan kemandirian peserta didik dengan menggunakan metode mendongeng cerita-cerita inspiratif dibantu oleh media boneka jari untuk lebih menarik perhatian peserta didik pada usia 4-5 tahun. Berdasarkan uraian yang ada, peneliti kemudian mengangkat judul "Peningkatan Kemandirian anak usia 4-5 tahun melalui metode mendongeng dengan media boneka jari di TK Pelangi Tenggarong Seberang Tahun Pelajaran 2016/2017."

\section{METODOLOGI PENELITIAN}

\section{Desain Penelitian}

Pendekatan yang digunakan dalam penelitian ini adalah pendekatan deskriptif kuantitatif jenis penelitian tindakan kelas (classroom action research) dengan model Kemmis dan Mc.Taggart. Menurut Kunandar (2013: 44), Penelitian Tindakan Kelas (PTK) didefinisikan sebagai suatu penelitian tindakan (action research) yang dilakukan oleh guru sekaligus sebagai peneliti di kelasnya dengan tujuan memperbaiki mutu praktik pembelajaran di kelas.

Penelitian tindakan kelas (PTK) model Kemmis dan Mc.Taggart dilakukan melalui proses yang dinamis dan komplementari yang terdiri dari 4 hal, yaitu : perencanaan (planning), tindakan (acting), observasi (observing), dan refleksi (reflecting). Keempat komponen penelitian tersebut di atas saling berkesinambungan dan merupakan ciri khas dari penelitian tindakan kelas (PTK).

\section{Subjek Penelitian}

Subjek dalam penelitian ini adalah peserta didik di TK Pelangi Tenggarong Seberang tahun ajaran 2016/2017. Berjumlah 16 Peserta didik, terdiri dari 7 anak laki-laki, dan 9 Anak perempuan.

\section{Objek Penelitian}

Objek dalam penelitian ini adalah tenaga pengajar di TK Pelangi Tenggarong Seberang tahun ajaran 2016/2017 yang menggunakan metode mendongeng dengan media boneka jari 
untuk meningkatkan kemandirian pada anak usia dini.

\section{Prosedur Penelitian}

Empat komponen penelitian tindakan kelas model Kemmis dan Mc.Taggart yang dilakukan secara singkat dijelaskan oleh Aqib (2014: 8) sebagai berikut : Penyusunan rencana (perencanaan), Tindakan. , Observasi dan Refleksi.

Menurut Arikunto (2006: 93), pada penelitian tindakan kelas (PTK) model Kemmis dan Mc.Taggart komponen tindakan dan observasi menjadi satu kesatuan karena kegiatan ini dilakukan secara simultan yang dapat digambarkan sebagai berikut:

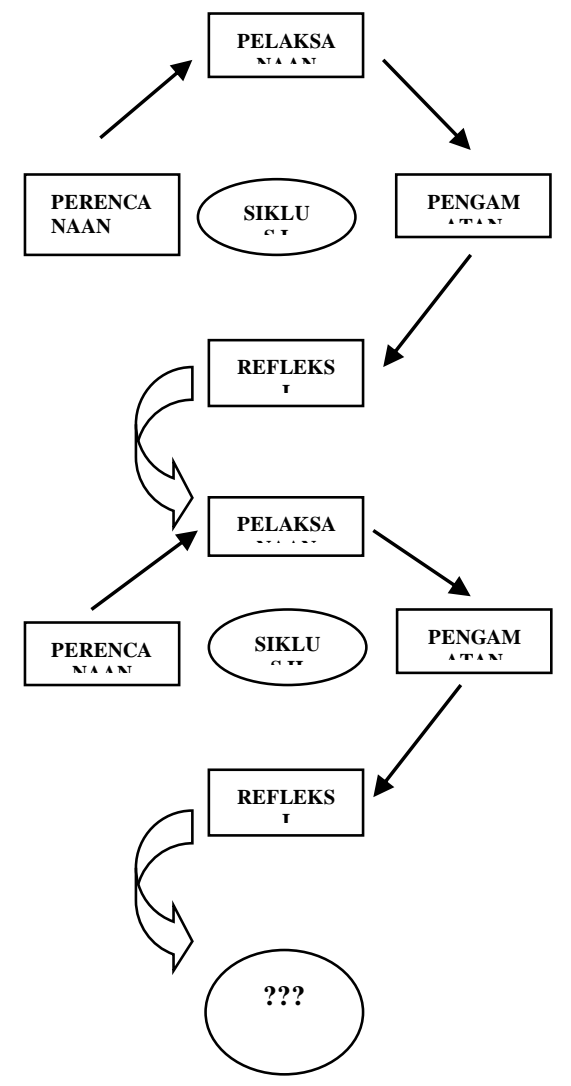

Gambar 1. Siklus Penelitian Tindakan Kelas

Berikut ini akan diterangkan mengenai tahapan-tahapan yang perlu disiapkan dan dilaksanakan pada saat melaksanakan sebuah penelitian tindakan kelas. Pelaksanaan penelitian yang akan dilaksanakan terdiri dari beberapa tahap, yakni :

\section{Siklus I}

\section{Perencanaan}

Tahap perencanaan dalam penelitian ini akan dilaksanakan dengan cara-cara sebagai berikut ini, diantaranya:

1) Membuat Rencana Kegiatan Harian (RKH) dan Rencana Kegiatan Mingguan (RKM) dengan tema Tanaman.

2) Menyiapkan media pembelajaran yang digunakan, yaitu boneka jari.

3) Menyiapkan instrumen pengamatan berupa panduan observasi untuk mengetahui kemandirian peserta didik.

\section{Pelaksanaan}

Dalam pelaksanaan penelitian tindakan kelas, terdapat 2 hal yang dilakukan secara bersamaan yaitu memberikan perlakuan kepada subjek penelitian dan juga mengamati berjalannya penelitian. Secara rinci pelaksanaan penelitian.

\section{Tindakan}

Peneliti melakukan tindakan pada Siklus 1 sebanyak 3 kali pertemuan, 
yang dilakukan di dalam kelas pada saat kegiatan awal selama 20 menit. Permainan dilakukan dengan 2 tahapan, yaitu tahap pra permainan dan inti permainan.

\section{Pengamatan}

Tahap pengamatan merupakan kegiatan mengamati tindakan yang dilakukan terhadap aktivitas peserta didik saat guru mendongeng dengan media boneka jari. Pengamatan berpedoman pada lembar instrument pengamatan, yaitu berupa panduan lembar observasi yang memuat nama peserta didik, aspek penilaian dan skor.

\section{Refleksi}

Tahap terakhir merupakan tahap refleksi yang meliputi kegiatan sebagai berikut:

1) Mengumpulkan data-data yang diperoleh dari hasil pengamatan.

2) Melakukan diskusi antara peneliti dan kolaborator untuk mengevaluasi hasil dari tindakan yang telah dilakukan, dan kendala yang muncul.

3) Mencari solusi terhadap kendalakendala yang mungkin muncul agar dapat dibuat perbaikan pada siklus selanjutnya.

4) Menganalisis hasil observasi kemandirian dan pengambilan keputusan, apabila hasil pengamatan belum mencapai target maka tindakan dilanjutkan pada siklus berikutnya sampai ada peningkatan yang telah diharapkan.

\section{Siklus II}

Tahapan pada siklus II sama seperti siklus sebellumnya yaitu siklus I. namun perencanaan yang dilakukan harus berupa pengembangan dari refleksi pada penerapan siklus I. adapun tahapan penelitian pada siklus II secara garis besar yaitu :

\section{Siklus III}

Siklus III merupakan tindak lanjut apabila masih terjadi kegagalan dalam penerapan siklus II. Tahapan-tahapan yang dilakukan pada siklus ini masih sama seperti pada siklus II, yaitu : Perencanaan, Pelaksanaan, Tindakan, Pengamatan dan Refleksi.

\section{Teknik Pengumpulan Data}

\section{Observasi}

Observasi digunakan pada penelitian ini dengan cara mengamati kemandirian peserta didik yang sesuai pada indikator penilaian yaitu Percaya diri; Bertanggung jawab; Disiplin; Mengendalikan emosi. Observasi dilakukan pada saat proses pembelajaran berlangsung, dengan menggunakan instrumen lembar observasi.

\section{Dokumentasi}

Metode ini digunakan oleh peneliti karena dapat melengkapi dan menguatkan data-data yang sudah 
diperoleh mengenai kemandirian peserta didik. Dokumen ini berupa catatan harian, lembar observasi dan buku laporan perkembangan anak.

\section{Instrumen Pengumpulan Data}

Analisis dilakukan pada setiap siklus dengan teknik deskriptif kuantitatif. Berikut ini rumus yang digunakan dalam analisis data dengan teknik diskriptif kuantitatif (Purwanto, 2006: 102) yaitu:

$$
\mathrm{NP}=\frac{\mathrm{R}}{\mathrm{SM}} \times 100 \%
$$

Keterangan :

$$
\begin{aligned}
& \mathrm{NP}=\text { Nilai persen yang dicari/ diharapkan } \\
& \mathrm{R}=\text { Skor mentah yang diperoleh } \\
& \mathrm{SM}=\text { Skor maksimum ideal dari nilai yang ada } \\
& 100 \%=\text { Konstanta/persentase maksimum }
\end{aligned}
$$

Rumus tersebut menjelaskan bahwa analisis data yang dilakukan menggunakan data yang dilakukan menggunakan data yang diperoleh dari skor pada hasil observasi, yaitu dengan menjumlah seluruh skor pada setiap indikator sehingga menghasilkan skor mentah (R) dan kemudian SM diperoleh dengan menghitung jumlah seluruh skor maksimum setiap indikator, lalu dimasukkan pada rumus tersebut sehingga tampak persentase hasil tindakan pada setiap indikator dan selanjutnya dihubungkan dengan persentase sebelum tindakan.

\section{Indikator Keberhasilan}

Penelitian ini dikatakan berhasil dengan baik apabila ada peningkatan pada siklus I,II dan III keberhasilan anak dalam menunjukkan kemandirian sebesar $80 \%$ seperti yang dijelaskan pada tabel berikut :

Tabel 1. Kategori penilaian hasil observasi

\begin{tabular}{|c|c|c|}
\hline $\begin{array}{c}\text { Presentasi } \\
\text { Keberhasilan } \\
\text { Belajar }\end{array}$ & $\begin{array}{c}\text { Kriteria } \\
\text { Penilaian }\end{array}$ & Nilai \\
\hline $80 \%-100 \%$ & Baik & 4 \\
\hline $60 \%-79 \%$ & Cukup & 3 \\
\hline $40 \%-59 \%$ & Kurang & 2 \\
\hline $20 \%-39 \%$ & Kurang Sekali & 1 \\
\hline \multicolumn{3}{|c|}{ Aqib, Zainal. 2014:8 }
\end{tabular}

\section{TEMUAN DAN PEMBAHASAN}

\section{Deskripsi sebelum siklus}

Sebelum melakukan tindakan, peneliti melakukan pengamatan awal berupa kegiatan sebelum siklus yang dilakukan pada bulan Oktober tahun 2017. Pengamatan ini dilakukan pada saat kegiatan menyimak cerita. Dalam kegiatan bercerita guru belum menggunakan media boneka. Pada waktu kegiatan tersebut sebagian besar anak tidak mendengarkan cerita akan tetapi malah asyik dengan temannya. Ketika guru memberikan pertanyaan, masih banyak ditemukan anak yang belum bisa menjawab pertanyaan terkait dengan cerita. Selain itu, anak mengalami kesulitan ketika diminta untuk menceritakan kembali isi cerita. Setelah kegiatan, peserta didik juga belum dapat bertanggung jawab untuk 
mengembalikan peralatan yang digunakan untuk bermain, dan beberapa masih menggunakan dengan kurang berhati-hati.

Dari hasil pengamatan awal yang telah dilakukan, menunjukkan bahwa kemandirian anak Kelompok A belum berkembang secara optimal. Sebagian besar anak belum bisa menceritakan kembali isi cerita, belum mampu menjalin hubungan baik dengan teman sebayanya, belum dapat bertanggung jawab untuk mengembalikan peralatan yang digunakan untuk bermain, dan beberapa masih menggunakan dengan kurang berhati-hati.

Langkah-langkah yang perlu dilakukan untuk mendongeng dengan menggunakan media boneka jari menurut Zaman (2014: 7.20) adalah sebagai berikut :

1. Sebagai pendahuluan, guru menyebutkan judul cerita untuk menarik minat peserta didik

2. Guru memasang sejumlah jarinya dengan boneka jari

3. Guru memberikan kesempatan pada peserta didik untuk mengikuti jalannya cerita dengan mendengarkan dialog atau komentar

4. Guru menggerakkan boneka jari dengan jalan menggerakkan jari ketika tokoh cerita sedang dialog;
5. Guru menjawab pertanyaan dan menanggapi komentar peserta didik agar lebih menghayati ceria

6. Guru memberikan kesempatan peserta didik untuk menceritakan kembali (mengkomunikasikan) cerita yang menggunakan boneka jari dengan bahasa sendiri secara individual

7. Guru memupuk dan mendorong keberanian peserta didik menceritakan kembali cerita yang dilihat

8. Guru melakukan pengamatan terhadap penampilan peserta didik yang meliputi aspek pengetahuan, kemampuan keterampilan, dan sikap.

Hasil pengamatan awal kemandirian peserta didik sebelum siklus adalah mampu Berani tampil menceritakan kembali dongeng yang disampaikan sebanyak 4 anak (25\%), mampu menjalin pertemanan dengan anak lain sebanyak 1 anak $(6,25 \%)$, sedangkan kemampuan mengembalikan alat permainan boneka jari pada tempatnya mulai berkembang sebanyak 10 anak (62,5\%) dan menggunakan boneka jari dengan hatihati mulai berkembang sebanyak 7 anak $(43,75 \%)$. Hal ini menunjukkan bahwa kemandirian pada peserta didik jelas belum berkembang dengan baik, sehingga peneliti melakukan upaya peningkatan 
kemandirian peserta didik kelompok A usia 4 - 5 tahun TK Pelangi Tenggarong Seberang dengan metode mendongeng menggunakan media boneka jari.

\section{Deskripsi Penelitian Siklus I}

Siklus I dilaksanakan 3 kali pertemuan, yaitu pada tanggal 1 hingga 3 Februari 2017 dengan tema tumbuhan. Uraian setiap pertemuan adalah sebagai berikut :

\section{Rekapitulasi Hasil Pengamatan Siklus}

\section{I}

Tabel 2. Data rekapitulasi kemandirian peserta didik usia $4-5$ tahun siklus I

\begin{tabular}{|c|c|c|c|c|c|}
\hline No. & $\begin{array}{l}\text { Aspek } \\
\text { penilaian }\end{array}$ & P 1 & P 2 & P 3 & $\begin{array}{l}\text { Nilai } \\
\text { rata - } \\
\text { rata }\end{array}$ \\
\hline 1 & $\begin{array}{l}\text { Berani } \\
\text { tampil } \\
\text { menceritakan } \\
\text { kembali } \\
\text { dongeng } \\
\text { yang } \\
\text { disampaikan. }\end{array}$ & $\begin{array}{l}25 \\
\%\end{array}$ & $\begin{array}{l}37, \\
5 \%\end{array}$ & $\begin{array}{l}43 \\
75 \\
\%\end{array}$ & $\begin{array}{l}35,42 \\
\%\end{array}$ \\
\hline 2 & $\begin{array}{l}\text { Menjalin } \\
\text { pertemanan } \\
\text { dengan anak } \\
\text { lain. }\end{array}$ & $\begin{array}{l}2,5 \\
0 \%\end{array}$ & $5 \%$ & $\begin{array}{l}1,2 \\
5 \%\end{array}$ & $\begin{array}{l}22,92 \\
\%\end{array}$ \\
\hline 3 & $\begin{array}{l}\text { Mengembali } \\
\text { kan alat } \\
\text { permainan } \\
\text { boneka jari } \\
\text { pada } \\
\text { tempatnya. }\end{array}$ & $\begin{array}{l}12 \\
50 \\
\%\end{array}$ & $\begin{array}{l}43 \\
75 \\
\%\end{array}$ & $\begin{array}{l}37, \\
5 \%\end{array}$ & $\begin{array}{l}31,25 \\
\%\end{array}$ \\
\hline 4 & $\begin{array}{l}\text { Menggunaka } \\
\mathrm{n} \text { boneka jari } \\
\text { dengan hati- } \\
\text { hati. }\end{array}$ & - & $\begin{array}{l}37, \\
5 \%\end{array}$ & $\begin{array}{l}31 \\
25 \\
\%\end{array}$ & $\begin{array}{r}3 \\
4,38 \%\end{array}$ \\
\hline \multicolumn{5}{|c|}{ Jumlah } & $\begin{array}{l}30,99 \\
\%\end{array}$ \\
\hline
\end{tabular}

Hasil pengamatan siklus I pertemuan 1, 2, dan 3 pada tabel di atas menunjukkan bahwa kemandirian peserta didik mengalami peningkatan dibandinkan dengan sebelum siklus sengan nilai rata-rata kemandirian pada siklus I sebesar 30,99\% maka penelitian dilanjutkan ke siklus II.

\section{Deskripsi Penelitian Siklus II}

Siklus II dilaksanakan 3 kali pertemuan, yaitu pada tanggal 6,8 dan 10 Februari 2017 dengan tema tumbuhan. Uraian setiap pertemuan sebagai berikut :

\section{Hasil Pengamatan Siklus II \\ Pertemuan $\mathrm{Ke}-1$}

\section{Rekapitulasi Hasil Pengamatan Siklus}

II

Rekapitulasi hasil pengamatan Siklus II pertemuan 1, 2, dan 3 menunjukkan rekapitulasi hasil di bawah ini :

Tabel 3 . Data rekapitulasi kemandirian peserta didik usia $4-5$ tahun siklus II

\begin{tabular}{|c|c|c|c|c|c|}
\hline $\begin{array}{l}\mathrm{N} \\
\mathrm{o} .\end{array}$ & Aspek penilaian & $\mathrm{P} 1$ & $\mathrm{P} 2$ & P 3 & $\begin{array}{l}\text { Nilai } \\
\text { rata } \\
- \\
\text { rata }\end{array}$ \\
\hline 1 & $\begin{array}{l}\text { Berani tampil } \\
\text { menceritakan } \\
\text { kembali dongeng } \\
\text { yang } \\
\text { disampaikan. }\end{array}$ & $\begin{array}{l}81,2 \\
5 \%\end{array}$ & $\begin{array}{l}81,25 \\
\%\end{array}$ & $\begin{array}{l}81, \\
25 \\
\%\end{array}$ & $\begin{array}{l}81,2 \\
5 \%\end{array}$ \\
\hline 2 & $\begin{array}{l}\text { Menjalin } \\
\text { pertemanan } \\
\text { dengan anak lain. }\end{array}$ & $\begin{array}{l}31,2 \\
5 \%\end{array}$ & $\begin{array}{l}43,75 \\
\%\end{array}$ & $\begin{array}{l}68, \\
75 \\
\%\end{array}$ & $\begin{array}{l}47,9 \\
2 \%\end{array}$ \\
\hline 3 & $\begin{array}{l}\text { Mengembalikan } \\
\text { alat permainan } \\
\text { boneka jari pada } \\
\text { tempatnya. }\end{array}$ & $50 \%$ & $\begin{array}{l}43,75 \\
\%\end{array}$ & $\begin{array}{l}68, \\
75 \\
\%\end{array}$ & $\begin{array}{l}54,1 \\
7 \%\end{array}$ \\
\hline 4 & $\begin{array}{l}\text { Menggunakan } \\
\text { boneka jari } \\
\text { dengan hati-hati. }\end{array}$ & $25 \%$ & $\begin{array}{l}31,25 \\
\%\end{array}$ & $\begin{array}{l}93, \\
75 \\
\%\end{array}$ & $50 \%$ \\
\hline \multicolumn{5}{|c|}{ Jumlah } & $\begin{array}{l}58,3 \\
4 \%\end{array}$ \\
\hline
\end{tabular}

\section{Hasil pengamatan siklus II} pertemuan 1, 2, dan 3 pada tabel di atas menunjukkan bahwa kemandirian peserta didik mengalami peningkatan dibandinkan dengan sebelum siklus sengan nilai rata - rata kemandirian 
pada siklus II sebesar 58,34 \% maka penelitian dilanjutkan ke siklus II.

\section{Deskripsi Penelitian Siklus III}

Silus III dilaksanakan 3 kali pertemuan, yaitu pada tanggal 13, 15 dan 17 Februari 2017 dengan tema tumbuhan. Uraian setiap pertemuan adalah sebagai berikut :

\section{Rekapitulasi Hasil Pengamatan Siklus} III

Rekapitulasi hasil pengamatan Siklus III pertemuan 1, 2, dan 3 menunjukkan rekapitulasi hasil di bawah ini :

Tabel 4. Data rekapitulasi kemandirian peserta didik usia $4-5$ tahun siklus III

\begin{tabular}{|l|l|l|l|l|l|}
\hline No. & Aspek penilaian & P 1 & P 2 & P 3 & $\begin{array}{l}\text { Nilai } \\
\text { rata - } \\
\text { rata }\end{array}$ \\
\hline 1 & $\begin{array}{l}\text { Berani tampil } \\
\text { menceritakan } \\
\text { kembali } \\
\text { dongeng yang } \\
\text { disampaikan. }\end{array}$ & $\begin{array}{l}100 \\
\%\end{array}$ & $\begin{array}{l}75 \\
\%\end{array}$ & $\begin{array}{l}85 \\
\%\end{array}$ & $\begin{array}{l}85,42 \\
\%\end{array}$ \\
\hline 2 & $\begin{array}{l}\text { Menjalin } \\
\text { pertemanan } \\
\text { dengan anak } \\
\text { lain. }\end{array}$ & $\begin{array}{l}68, \\
75\end{array}$ & $\begin{array}{l}68, \\
75\end{array}$ & $\begin{array}{l}10 \\
0 \%\end{array}$ & $\begin{array}{l}\% \\
79,12\end{array}$ \\
\hline 3 & $\begin{array}{l}\text { Mengembalikan } \\
\text { alat permainan } \\
\text { boneka jari } \\
\text { pada } \\
\text { tempatnya. }\end{array}$ & $\begin{array}{l}100 \\
\%\end{array}$ & $\begin{array}{l}87, \\
5 \%\end{array}$ & $\begin{array}{l}75 \\
75\end{array}$ & $\begin{array}{l}93,75 \\
\%\end{array}$ \\
\hline 4 & $\begin{array}{l}\text { Menggunakan } \\
\text { boneka jari } \\
\text { dengan hati- } \\
\text { hati. }\end{array}$ & $\begin{array}{l}87, \\
5 \%\end{array}$ & $\begin{array}{l}75 \\
\%\end{array}$ & $\begin{array}{l}87, \\
5 \%\end{array}$ & $\begin{array}{l}83,33 \\
\%\end{array}$ \\
\hline \multirow{2}{*}{ Jumlah } \\
\hline
\end{tabular}

Hasil pengamatan siklus III pertemuan 1, 2, dan 3 pada tabel di atas menunjukkan bahwa kemandirian peserta didik mengalami peningkatan dibandingkan dengan siklus II dengan nilai rata - rata kemandirian pada siklus
II sebesar $85,41 \%$ maka penelitian ini dinyatakan berhasil.

Peningkatan yang teerjadi pada Kemandirian anak usia $4-5$ tahun pada setiap siklus menunjukkan bahwa metode mendongeng menggunakan media boneka jari berhasil diterapkan di TK Pelangi Tenggarong Seberang. Berikut tabel peningkatan kemandirian peserta didik antar siklus :

Tabel 5. Peningkatan kemandirian antar

\begin{tabular}{|c|c|c|c|c|c|}
\hline \multicolumn{6}{|c|}{ siklus } \\
\hline $\begin{array}{l}\mathrm{N} \\
\mathrm{o}\end{array}$ & $\begin{array}{l}\text { Aspek yang } \\
\text { dinilai }\end{array}$ & $\begin{array}{l}\text { Pra } \\
\text { Siklus }\end{array}$ & $\begin{array}{l}\text { Siklus } \\
\text { I }\end{array}$ & $\begin{array}{l}\text { Siklus } \\
\text { II }\end{array}$ & $\begin{array}{l}\text { Siklu } \\
\text { s III }\end{array}$ \\
\hline 1 & $\begin{array}{l}\text { Berani tampil } \\
\text { menceritakan } \\
\text { kembali } \\
\text { dongeng } \\
\text { yang } \\
\text { disampaikan. }\end{array}$ & $25 \%$ & $\begin{array}{l}35,42 \\
\%\end{array}$ & $\begin{array}{l}81,25 \\
\%\end{array}$ & $\begin{array}{l}85,42 \\
\%\end{array}$ \\
\hline 2 & $\begin{array}{l}\text { Menjalin } \\
\text { pertemanan } \\
\text { dengan anak } \\
\text { lain. }\end{array}$ & $6,25 \%$ & $\begin{array}{l}22,92 \\
\%\end{array}$ & $\begin{array}{l}47,92 \\
\%\end{array}$ & $\begin{array}{l}79,12 \\
\%\end{array}$ \\
\hline 3 & $\begin{array}{l}\text { Mengembalik } \\
\text { an alat } \\
\text { permainan } \\
\text { boneka jari } \\
\text { pada } \\
\text { tempatnya. }\end{array}$ & $0 \%$ & $\begin{array}{l}31,25 \\
\%\end{array}$ & $\begin{array}{l}54,17 \\
\%\end{array}$ & $\begin{array}{l}93,75 \\
\%\end{array}$ \\
\hline 4 & $\begin{array}{l}\text { Menggunaka } \\
\mathrm{n} \text { boneka jari } \\
\text { dengan hati- } \\
\text { hati. }\end{array}$ & $0 \%$ & $\begin{array}{l}34,38 \\
\%\end{array}$ & $50 \%$ & $\begin{array}{l}83,33 \\
\%\end{array}$ \\
\hline & Ketuntasan & $7,81 \%$ & $\begin{array}{l}30,99 \\
\%\end{array}$ & $\begin{array}{l}58,86 \\
\%\end{array}$ & $\begin{array}{l}85,41 \\
\% \%\end{array}$ \\
\hline
\end{tabular}

Untuk mengetahui peningkatan kemandirian peserta didik mulai dari sebelum siklus hingga siklus III, dapat dilihat dari grafik di bawah ini 


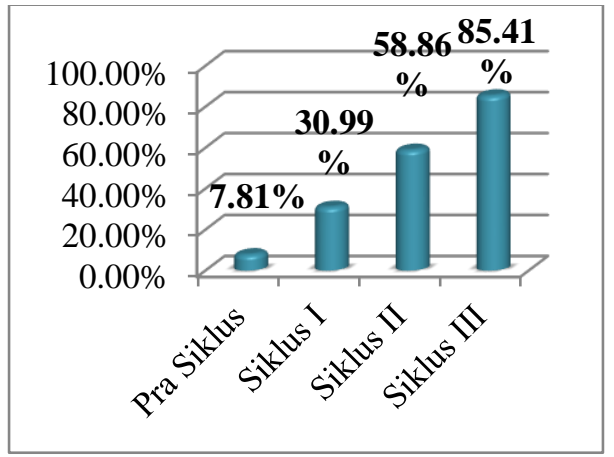

Grafik 1. Peningkatan kemandirian antar siklus

\section{PEMBAHASAN}

Hasil penelitian tindakan kelas dalam upaya peningkatan kemandirian anak usia 4 - 5 tahun melalui metode mendongeng dengan media boneka jari di tk pelangi tenggarong seberang Tahun pelajaran 2016/2017 adalah sebagai berikut :

1. Secara umum meningkatnya kemandirian anak usia 4 - 5 tahun dari siklus I ke siklus II menunjukkan peningkatan kualitas pada beberapa kriteria seperti kemampuan Berani tampil menceritakan kembali dongeng yang disampaikan, menjalin pertemanan dengan anak lain, mengembalikan alat permainan boneka jari pada tempatnya, dan menggunakan boneka jari dengan hati-hati. Hasil yang didapatkan pada penelitian awal sebelum siklus menunjukkan kemandirian peserta didik yang masih sangat rendah yakni $7,81 \%$ pada kategori berkembang sesuai harapan. Hasil tersebut meningkat pada siklus I setelah guru menerapkan metode mendongeng menggunakan media boneka jari yakni menjadi sebesar 30,99\%. Peningkatan kembali terjadi pada siklus II yakni kemandirian peserta didik menjadi sebesar 58,86\%. Hasil tersebut belum memenuhi kriteria ketuntasan, sehingga peneliti kembali melanjutkan penelitian pada siklus III hingga didapatkan hasil sebesar 85,41\%. Keempat nilai tersebut di dapat berdasarkan jumlah dari kategori penilaian berkembang sesuai harapan dan berkembang sangat baik.

2. Peningkatan kemandirian pada anak usia 4 - 5 tahun pada setiap siklus ini didukung oleh pendapat Arbya (2011: 1) yang mengatakan bahwa kemandirian bukanlah keterampilan yang muncul tiba-tiba tetapi perlu diajarkan pada anak. Tanpa diajarkan, anak-anak tidak tahu bagaimana harus membantu dirinya sendiri. Kemampuan bantu diri inilah yang dimaksud dengan mandiri. Metode pengajaran yang digunakan peneliti adalah mendongeng dengan media boneka jari, dimana dalam setiap proses pembelajaran, guru terus menuntun 
dan mengajarkan kepada peserta didik untuk terus membiasakan diri agar hidup lebih mandiri. Metode ini rupanya mampu meningkatkan kemandirian bagi anak usia $4-5$ tahun.

3. Peningkatan masing-masing indikator penilaian yang diamati, menurut Peraturan Menteri Pendidikan Nasional nomor 58 tahun 2009 tentang standar pendidikan anak usia dini, indikator kemandirian dan karakteristik sosial emosional anak usia 4-5 tahun, yaitu berinteraksi dengan teman sebaya dan orang dewasa, menunjukkan rasa percaya diri, menunjukkan kemandirian, dan mulai bertanggung jawab dikembangkan kedalam indikator penilaian yakni berani tampil menceritakan kembali dongeng yang disampaikan, menjalin pertemanan dengan anak lain, mengembalikan alat permainan boneka jari pada tempatnya, dan menggunakan boneka jari dengan hati-hati.

\section{PENUTUP}

\section{Kesimpulan}

Rata-rata kemandirian seluruh anak dalam setiap aspek penilaian mengalami peningkatan, dari prasiklus ke siklus I dari $7,81 \%$ menjadi $27,08 \%$ atau sebesar 19,27\%. Kemudian, penelitian dilanjutkan karena persentase ketuntasan siklus I belum memenuhi kriteria pencapaian hasil yaitu $80 \%$. Dari siklus I ke siklus II kemandirian anak mengalami peningkatan dari $27,08 \%$ menjadi 58,86\% atau sekitar $31,78 \%$. Peneliti kembali melanjutkan penelitian ke siklus III. Hasil penelitian menunjukkan perkembangan yang sangat baik karena terjadi peningkatan kemandirian anak dari 58,86\% menjadi $85,41 \%$ atau meningkatan sebesar $36,55 \%$. Masalah yang paling terlihat adalah pada siklus I dimana anak belum menunjukkan respon yang berarti ketika diminta untuk menceritakan kembali dongeng yang disajikan oleh guru, beberapa anak juga belum menunjukkan kemampuannya dalam menjalin hubungan dengan orang lain.

\section{Saran}

1. Bagi sekolah dapat lebih mendukung secara intensif pembelajaran dengan menggunakan metode mendongeng dengan media jari.

2. Bagi guru hendaknya dapat menerapkan metode mendongeng dengan media boneka jari secara konsisten bahkan hingga mengembangkannya demi mencapai tujuan pembelajaran yang 
lebih baik terutama pada kemandirian anak.

\section{DAFTAR PUSTAKA}

Abdul, Muhammad Latif. 2014. Mendongeng Mudah dan Menyenangkan. Jakarta Timur: Luxima Metro Media. Hal. 3

Anonim. 2012. Boneka Jari menghidupkan imajinasi si kecil. http://news.liputan6.com/read/4193 66/boneka-jari-hidupkan-imajinasi-

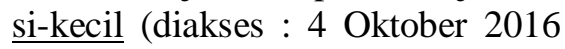
19:30)

Aqib, Zainal. 2014. Penelitian Tindakan Kelas. Bandung : Yrama Widya. Hal. 8

Arbya, Nety 2011. Membentuk Kemandirian Anak. [online]. Tersedia http://mamahebat.wordpress.com/2 011/01/05/membentukkemandirian-anak/ (diakses : 15 September 2016 01:34)

Asrori, Mohammad. 2008. Psikologi Pembelajaran. Bandung: Wacana Prima. Hal. 130

Azzet, Akhmad Muhaimin. 2014. Mengembangkan Kecerdasan Sosial bagi Anak. Jogjakarta: Katahati. Hal. 30

Departemen Pendidikan Nasional. 2010. Kurikulum Taman Kanak-kanak (Pedoman Pengembangan Program Pembelajaran di Taman Kanak-kanak). Jakarta: Kementerian Pendidikan Nasional, Direktorat Jenderal Manajemen Pendidikan Dasar dan Menengah, Direktorat Pembinaan Taman Kanak-kanak dan Sekolah Dasar. Hal. 3
Departemen Pendidikan Nasional. 2004. Kurikulum 2004 Taman Kanakkanak dan Raudlatul Athfal. Jakarta: Departemen Pendidikan Nasional, Direktorat Jenderal Manajemen Pendidikan Dasar dan Menengah. Hal. 1

Hidayat, O.S,. 2007. Metode Pengembangan Moral dan Nilainilai agama. Jakarta: Universitas Terbuka. Hal. 4.12

Hildayani, Rini., dkk. 2012. Materi Pokok Psikologi Perkembangan anak. Tangerang Selatan: Universitas Terbuka. Hal. 4.3

Kunandar. 2008. Langkah Mudah Penelitian Tindakan Kelas Sebagai Pengembangan Profesi Guru. Jakarta: Raja Grafindo Persada. Hal. 44

Lie, Anita dan Sarah Prasasti. 2004. Menjadi Orang Tua Bijak 101 Cara Membina Kemandirian dan Tanggung Jawab Anak. Jakarta: PT Elex Media Komputindo. Hal. 44

Madyawati, Lilis. 2016. Strategi Pengembangan Bahasa Pada Anak. Jakarta: Prenamedia. Hal 144

Montolalu. 2014. Bermain Dan Permainan Anak. Tangerang Selatan: Universitas Terbuka. Hal. 1.10

Pangastuti, Ratna. 2014. Edutainment Pendidikan Anak Usia Dini. Yogyakarta: Pustaka Pelajar. Hal. 15

Purwanto, Ngalim. 2006. PrinsipPrinsip dan Teknik Evaluasi Pengajaran. Bandung: Rosda Karya. Hal. 102

Sabariah, Lusiana. 2016. Mari Mendongeng Panduan Belajar 
Mendongeng. Yogyakarta: Zora Book. Hal. xvii

Satibi H., Otib. 2012. Materi Pokok Metode Pengembangan Moral dan Nilai-nilai Agama. Jakarta :Universitas Terbuka. Hal. 4.17

Sidharto, Suryati., dkk. 2007. Sosial Life Skill untuk Anak Usia Dini Modul 3 Pengembangan Kebiasaan Positif. Yogyakarta: Tiara Wacana. Hal. 16

Soefandi, Indra. 2009. Strategi Mengembangkan Potensi Kecerdasan Anak. Jakarta: Bee Media Indonesia. Hal. 7

Surya, Hendra. 2003. Kiat Mengajak Anak Belajar dan Berprestasi. Jakarta: Elex Media Komputindo. Hal. 114

Suryana, Dadan. 2013. Materi Pokok Dasar-dasar Pendidikan TK. Tangerang Selatan: Universitas Terbuka. Hal. 1.3

Syaodih, Ernawulan. (2005). Bimbingan di Taman Kanak-kanak. Jakarta: Departemen Pendidikan Nasional, Direktorat Jenderal Pendidikan Tinggi, Direktorat Pembinaan Pendidikan Tenaga Kependidikan dan Ketenagaan Perguruan Tinggi. Hal. 31

Wibowo, Agus. 2013. Strategi Membangun Karakter di Usia Emas. Yogyakarta: Pustaka Pelajar. Hal. 1

Yamin, Martinis. 2010. Panduan Pendidikan Anak Usia Dini. Jakarta: Gaung Persada Press. Hal. 4

Zaman, Badru. 2014. Materi Pokok Media dan Sumber Belajar. Tangerang Selatan: Universitas Terbuka. Hal. 7.20 